INTERNATIONAL JOURNAL OF RESEARCHES IN BIOSCIENCES, AGRICULTURE AND TECHNOLOGY (C) VISHWASHANTI MULTIPURPOSE SOCIETY (Global Peace Multipurpose Society) R. No. MH-659/13(N) www.vmsindia.org

\title{
ENUMERATION OF CAUSES AND SOURCES RESPONSIBLE FOR DETERIORATION OF RURAL WATER BODIES: ASSESSMENT OF POTABLE WATER QUALITY
}

\author{
A. D. Bobdey and K. T. Waghmare \\ S.S.E.S. Science College, Congress Nagar, Nagpur, (M.S.) India, 440012. \\ drad.bobdey@sscn.in
}

\begin{abstract}
:
The proposed work will deal with the study of four rural lakes and its present environmental status. 1) Adyal lake, 2)Madgi lake, 3) Kesalwada lake and 4) Wahi lake. First three lakes are located in the rural areas nearby localities and Wahi lake is located far away from the localities where less human activities are observed.The water of all four lakes is presently used for irrigation and drinking of cattles in rural area, but the present scarcity of water in the region, may alter the use of lakes for main drinking purposes. A general survey of study area was made for the study of ecological parameters. Data harvested from experimental analysis of Lake Water and overall seasonal survey of selected water bodies indicates that the direct and indirect human activities are mainly responsible to deteriorate the surface water quality of the study area. Agricultural farming of watermelon, musk melon along the bank of lake and farms of Trapa natans (Water chestnut) in the basin of lake is a frequent practices in study area. The use of fertilizers and pesticides over the emergent aquatic vegetation makes the situation more miserable.
\end{abstract}

Keywords: Agriculture, areal runoff, pollution, lake, BOD, Temperature, pH.

\section{Introduction:}

Water is one of the most important and precious of natural resources and a regular and plentiful supply of clean water is essential for the survival and health of all living organisms. A huge quantity of fresh water is available on our planet; almost 1500 million cubic kms (Penman, 1970). However, $70 \%$ of available water is of no use as it contains significant quantity of salt. Total amount of available fresh water on our planet is only about 84.4 cubic $\mathrm{kms}$, of which $70 \%$ water is in frozen state in the form of snow caps, ice sheets, glaciers etc. Thus, less than $1 \%$ of water remains for human use and that too which is unusually distributed all around the earth. This constant amount of water passes through a system of hydrobiological cycle.

The water in the form of rain or snow reaches the earth; it flows in rivers and is finally collected in lakes and oceans. It is called as "surface water". This water in-turn evaporates to fall again as precipitation. Some amount of water penetrates in to the soil to become ground water, out of which plant roots absorb some water. The water that is consumed by plant is returned to the atmosphere through transpiration process.

Coulson and Frobes (1952), defined water pollution as the addition of some thing to water, which changes its natural qualities. Alternately, it has been defined as the addition of anything, causing or inducing objectionable conditions in any water and affecting adversely, if utilized.

Water is regarded as 'polluted' when it is changed in its quality or compositions, directly or indirectly as a result of human activities, so that it becomes less suitable for drinking, as well as domestic and other purposes. As a consequence of rapidly expanding industrial areas and excessive population growth, most of our rivers, lakes, streams and other water bodies are being increasingly polluted. Pollution of fresh water results largely from the waste disposal. Many of our lakes are becoming increasingly murky, smelly andchoked with excessive growth of algae. Most of the rivers have become darkened with sewage, chemicals, industrial effluents and other undesirable foreign extraneous matter. The rivers commonly carry sewage, industrial effluents and agricultural runoff, which include fertilizers and pesticides. Moreover, the rivers carry and deposit their pollutants in to the ocean. Thus, the oceans are also polluted by toxic wastes which cause contamination of sea foods on a large-scale.

The growing load of environmental pollution has resulted in to an increase in the degree of civilization damage. There is a worldwide concern about the pollution of water due to human activity. Nature is a great cleansing agent but it has limitations as far as its capacity to assimilate pollutants. River water is considered to be relatively pollutant-free as compared to stagnant water bodies because flowing water permits dispersion of pollutants over a large area and thus, diluting them to a great extent.

\section{Material and Method:}

Perusal of previous records showed that the lakes along the region was relatively pollution free. Thereafter the increased human activities due to population explosion and 
scarcity of drinking water in the region may provide more stress on the rural water bodies and its aquatic ecosystem. The quality of surface waters along the region going on deteriorating on certain levels. In such situation, it is very necessary to assess the causes and sources of contamination by assessment of water quality parameters of lake water with its relative biotic components.

On the other hand in future, due to scarcity of drinking water, the water from this source possibly may be used for drinking purpose of the locality. The influx of pollutants from the different sources and human activities along the lake must have alter the water chemistry of the lake, which may intern affect the associated biota of the water body. (Mukherjee et al, 1994).

The proposed work will deal with the study of four rural lakes and its present environmental status. 1)Adyal lake, 2)Madgi lake, 3)Kesalwada lake and 4)Wahi lake. First three lakes are located in the rural areas nearby localities and Wahi lake is located far away from the localities where less human activities are observed. The water of all four lakes is presently used for irrigation and drinking of cattles in rural area, but the present scarcity of water in the region, may alter the use of lakes for main drinking purposes. A general survey of study area was made for the study of ecological parameters. In view of human activities, four sampling stations have been selected around the dam.

The acquisition of meaningful data demands correct sampling and preservation procedures. It has been scientifically proved that the shorter the time interval between sample collection and analysis, more the accurate are the results. The analysis of water samples are to be perform preferably in the field. The preservation of samples is done by refrigeration at $4 \circ \mathrm{C}$, and use of $4 \%$ formalin to preserve the zooplanktons, which is the most general accepted method.

The analysis of certain parameters such as, Temperature, $\mathrm{pH}$, Conductivity, Total dissolved solids and Dissolved oxygen is performed in the field by using portable water analysis kit and Chlorides, Biochemical Oxygen Demand, by the laboratory techniques given by NEERI (1984)

\section{Result and Discussion:}

Data harvested from experimental analysis of Lake Water and overall seasonal survey of selected water bodies indicates that the direct and indirect human activities are mainly responsible to deteriorate the surface water quality of the study area.

During a survey of the lake contain facts regarding to contamination of lake waters are enlightening. Decline the value of physicchemical parameter of Adyal Lake showed that the input of the heavy organic load of water mainly due to cattle activities. However, in Madgi Lake and Kesalwada Lake same situation is observed, The lakes are mercilessly used for washing and bathing activities, which causes increase in load of pollutants and reduction of dissolved oxygen and enhanced values of biochemical oxygen demand, (Table 1.3, 1.4). The lake is only a source of drinking water for cattle; especially buffalo is the main cause of lake pollution. Daily two or more visits of group of cattle's to lake mix plenty of organic matter in water. Traditional rural cattle houses sticks plenty of dung to the body lake deteriorate water quality. of cattle's, washing of cattle along the bank of river and lakes.

During summer the condition became more miserable less water in the lake offer more concentration to the pollutants, and resting of buffaloes in lake water continuously mixes the bottom sediments along the surface of water.

Biochemical oxygen demand of Madgi, Kesalwada and Adyal Lake indicates the amount of organic matter in water bodies. In summer season pear of BOD and conductivity value are due to cattle activities.

Besides that, presence of rice fields along the bank of the lakes contaminates water with seepage of fertilizers and pesticides, which enhance the chlorine concentration in water. In Adyal, Madgi and Kesalwada lakes washing activities by localities are recorded.

Dumping of Garbage along the bank of these three lakes contaminates water during rainy season due to surface runoff materials.

Agricultural farming of watermelon, musk melon along the bank of lake and farms of Trapa natans (Water chestnut) in the basin of lake is a frequent practices in study area. The use of fertilizers and pesticides over the emergent aquatic vegetation makes the situation more miserable. All lakes maintain the well alkaline nature of water. (Bobdey A. D. et al., 2009)

During summer hot evaporation of water and addition of decaying leaves increased the value of biochemical demands. In all, increased input of the falling leaves of higher vegetation increase the $B O D$ values of the Kesalwada and Madgi lakes during summer season, it may be due to combine effect of less 
water and input of plant oriented organic matter in the lake.

Temperature of lake water influences by the solar intensity and temperature of air Carbonates and bicarbonates oriented from organic input and bottom sediments maintains the well alkaline rate of lake water.

The study of lakes during the rainy season reveals that runoff, soil and organic matter play an important role in discharging pollutants in the water bodies. Ariel oxygen and turbulence of water during rains maintains the DO of lake water. (Prakasam V.R. 2003)

Bio-degradation of bottom sediments and mixing of other organic substances lowers the value of D.O. and increase B.O.D. of lake water.

Total dissolved solid in the water bodies showed different observations. Increased level of T.D.S. may be due to surface runoff soil.

Winter study showed the optimum level of parameters in lakes. Respiration of aquatic flora during day time and release $\mathrm{O}_{2}$ in the lake maintains the level of DO in water.

\section{Conclusion:}

The significant source of contamination in Madgi, Adyal and Kesalwada Lake is the direct or indirect deposition of garbage and cattle activities. However the wahi Lake is well protected from the human activities as it is located in the forest area away from the locality.

Table.1.1: Variation in physico chemical parameters in Wahi Lake.

\begin{tabular}{|l|c|c|c|}
\hline \multicolumn{1}{|c|}{ Parameter } & $\begin{array}{c}\text { Rainy } \\
\text { Season }\end{array}$ & $\begin{array}{c}\text { Winter } \\
\text { Season }\end{array}$ & $\begin{array}{c}\text { Summer } \\
\text { Season }\end{array}$ \\
\hline BOD & 6.1 & 5.8 & 6.2 \\
\hline Chlorides & 165 & 169 & 184 \\
\hline DO & 8.3 & 6.8 & 4.9 \\
\hline $\begin{array}{l}\text { Electrical } \\
\text { Conductivity }\end{array}$ & 969 & 674 & 889 \\
\hline pH & 7.4 & 7.3 & 7.5 \\
\hline Temperature & 25.8 & 24.5 & 28.2 \\
\hline TDS & 672 & 593 & 684
\end{tabular}

Table. 1.2: Variation in physico chemical parameters in Adyal Lake.

\begin{tabular}{|l|c|c|c|}
\hline \multicolumn{1}{|c|}{ Parameter } & $\begin{array}{c}\text { Rainy } \\
\text { Season }\end{array}$ & $\begin{array}{c}\text { Winter } \\
\text { Season }\end{array}$ & $\begin{array}{c}\text { Summer } \\
\text { Season }\end{array}$ \\
\hline BOD & 12.3 & 10.4 & 16.8 \\
\hline Chlorides & 44 & 39.2 & 53 \\
\hline DO & 6.3 & 6.1 & 4.1 \\
\hline $\begin{array}{l}\text { Electrical } \\
\text { Conductivity }\end{array}$ & 851 & 636 & 929 \\
\hline pH & 7.3 & 7.1 & 7.5 \\
\hline Temperature & 24.5 & 22.7 & 28.9 \\
\hline TDS & 328 & 219 & 569
\end{tabular}

Table.1.2: Variation in physico chemical parameters in Madgi Lake.

\begin{tabular}{|l|c|c|c|}
\hline \multicolumn{1}{|c|}{ Parameter } & $\begin{array}{c}\text { Rainy } \\
\text { Season }\end{array}$ & $\begin{array}{c}\text { Winter } \\
\text { Season }\end{array}$ & $\begin{array}{c}\text { Summer } \\
\text { Season }\end{array}$ \\
\hline BOD & 9.3 & 9.4 & 14.9 \\
\hline Chlorides & 162 & 146 & 143 \\
\hline DO & 5.6 & 5.3 & 4.2 \\
\hline $\begin{array}{l}\text { Electrical } \\
\text { Conductivity }\end{array}$ & 384 & 394 & 416 \\
\hline pH & 6.1 & 7.5 & 7.2 \\
\hline Temperature & 24.2 & 21.9 & 28.7 \\
\hline TDS & 665 & 592 & 569 \\
\hline
\end{tabular}

Table.1.2: Variation in physico chemical parameters in Kesalwada Lake.

\begin{tabular}{|l|c|c|c|}
\hline \multicolumn{1}{|c|}{ Parameter } & $\begin{array}{c}\text { Rainy } \\
\text { Season }\end{array}$ & $\begin{array}{c}\text { Winter } \\
\text { Season }\end{array}$ & $\begin{array}{c}\text { Summer } \\
\text { Season }\end{array}$ \\
\hline BOD & 8.6 & 6.3 & 10.4 \\
\hline Chlorides & 172 & 184 & 195 \\
\hline DO & 4.8 & 4.1 & 3.2 \\
\hline $\begin{array}{l}\text { Electrical } \\
\text { Conductivity }\end{array}$ & 373 & 382 & 421 \\
\hline pH & 8.2 & 7.6 & 7.8 \\
\hline Temperature & 22.4 & 23.2 & 28.5 \\
\hline TDS & 631 & 571 & 563 \\
\hline
\end{tabular}

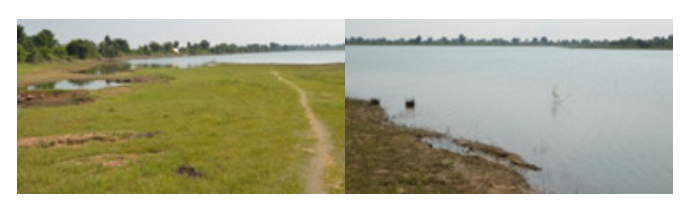

Fig.1- Photographs to show Wahi lake

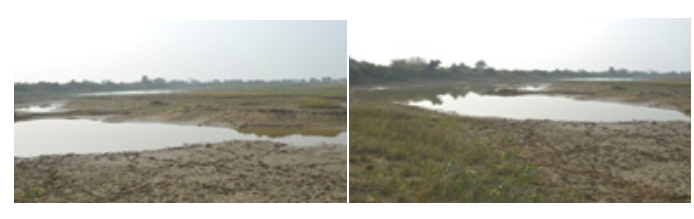

Fig.2- Photographs to show Adyal lake

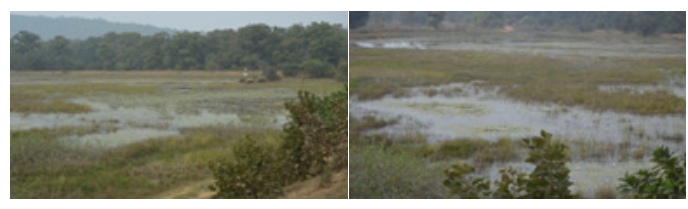

Fig.3- Photographs to show Madgi lake

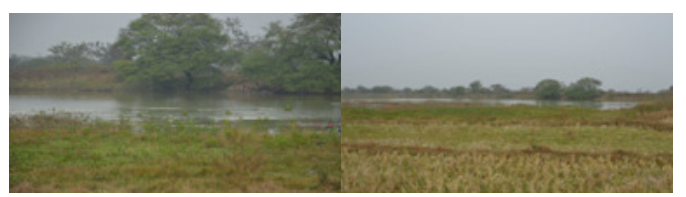

Fig.4- Photographs to show Kesalwada lake 


\section{Acknowledgement:}

Authors are thankful to University Grants Commission, New Delhi, for offering a chance to perform this precious research work. Thankfulness is also due to Honourable Dr. Devendra Burghate, principal of the college, to create vision among us to perform society related research work with continuous motivation and kind help during the research work. We also indebted to Honourable Adv. Arunkumar Shelke, President of Shri Shivaji Education Society, Amravati, for his kind assessment of our research work time to time with his team of higher education. Last but not least we are also thankful to our beloved collegues Dr. Ms. S. V. Ghonmode, Dr. Mrs. S. G. Kadu and Dr. Ms. S. S. Deshmukh and Mr. Prashant Ingle, whom keen interest in the subject and scholarly discussion about the results of research work provide us the more accurate collection and interpretation data.

\section{References:}

APHA (1985): Standard methods for the examination of water and waste water, 16th Ed. American public health association. American water works association, Water Pollution Control Federation, Washington D.

Bobdey A. D., Bhagat V.B., Meshram C. B., and Dhande R. S. (2009) : "Trophic status of Ambadi Dam in Relation to Physico Chemical Characteristics of its water' Biosci. Biotech. Res. Comm., Vol. (2), No. (2), December, 2009 : 214216.

Mukherji B., Pankajakshi G.V.N., Bose P., Kumar R.,Kumar P., Kumar D.,Kumar A., Kumar R., Singh S., and Kanogia S. (1994). '
The phosphate load from detergent imputs and its effect in fresh waters,. J. Environ. Biol., 15 ) : 27-39

NEERI (1984) : 'A manual of water and waste water analysis', National Environmental Engineering Research Institute, Central India, Nagpur (M.S.).

Penman H. L. (1970) : ' The water Cycle' Scientific American, 233 (3) : 99. A

Prakasam V.R. (2003) : ' Limnological studies on Sasthamcotta Lake - A, fresh water Ramsar site'., Indian J. Environ and Ecoplan., 7 (2), 239-242.

Roger S. P. (1991) : " Fresh water. In global possible : Resource development and new centuary'. R., Aff. EW. Press, New Delhi.

Subhashini S. and Saradhamani (2004) : ' Hydrobiology of Aliyar Reservoir, Coimbatore district, India.', Indian J. Environ and Ecoplan., 8 (3), 715-718.

Thomas S., Harikrishnan K., George S., Paulmurugan R. and Das M. R. (2001) : ' Studies on the water quality of Kutanad Wetland Ecosystem, Kerala'., Poll. Res, 20, (1), 59-66.

Wetzel R. G. (1983) : ' Limnology'., 2nd Edn. Saundars Coll. Publ., 767.

Yadav R. N. (2007) : ' Seasonal variation and species diversity of Macrozoobenthic communities of tropical lake'., LIMNOLOGY, DAE-BRNS, Nat. Symp. Proc., C.P.-24, 211-214. 